\title{
Demonstrating and Evaluating Heavy-Duty Alternative Fuel Operations
}

\author{
Trucking Research Institute \\ Alexandria, VA
}

\section{Principal Investigator: William Peerenboom \\ NREL Technical Monitor: Paul Norton}

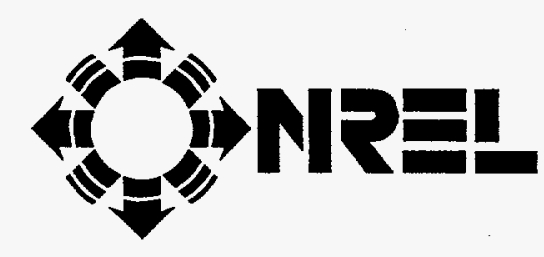

Alternative Fuels Hotline: 1-800-423-1DOE

Alternative Fuels Data Center World Wide Web Site: http://www.afdc.doe.gov

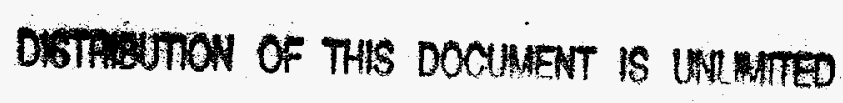

National Renewable Energy Laboratory

1617 Cole Boulevard

Golden, Colorado 80401-3393

A national laboratory of the

U.S. Department of Energy

Managed by the Midwest Research Institute

For the U.S. Department of Energy

Under Contract No. DE-AC36-83CH10093

Prepared under Subcontract Number XC-1-111134-1

February 1998 


\section{NOTICE}

This report was prepared as an account of work sponsored by an agency of the United States government. Neither the United States government nor any agency thereof, nor any of their employees, makes any warranty, express or implied, or assumes any legal liability or responsibility for the accuracy, completeness, or usefulness of any information, apparatus, product, or process disclosed, or represents that its use would not infringe privately owned rights. Reference herein to any specific commercial product, process, or service by trade name, trademark, manufacturer, or otherwise does not necessarily constitute or imply its endorsement, recommendation, or favoring by the United States govemment or any agency thereof. The views and opinions of authors expressed herein do not necessarily state or reflect those of the United States government or any agency thereof.

Available to DOE and DOE contractors from:

Office of Scientific and Technical Information (OSTI)

P.O. Box 62

Oak Ridge, TN 37831

Prices available by calling (423) 576-8401

Available to the public from:

National Technical Information Service (NTIS)

U.S. Department of Commerce

5285 Port Royal Road

Springfield, VA 22161

(703) $487-4650$ 


\section{DISCLAIMER}

Portions of this document may be illegible electronic image products. Images are produced from the best available original document. 


\section{Contents}

Introduction $\ldots \ldots \ldots \ldots \ldots \ldots \ldots \ldots \ldots \ldots \ldots \ldots \ldots \ldots \ldots \ldots \ldots \ldots \ldots$

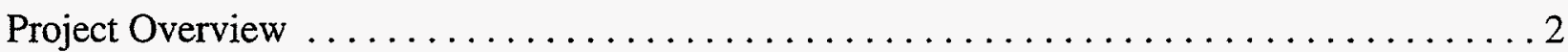

Narrative History of Program Development $\ldots \ldots \ldots \ldots \ldots \ldots \ldots \ldots \ldots \ldots \ldots$

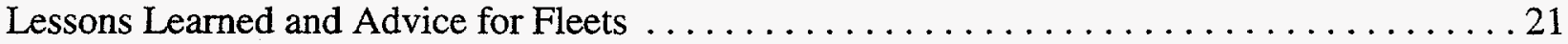

Appendix 1: Vehicle Specifications, NREL-ATA Foundation Demonstration Projects . . . . 1-1

Appendix 2: Members of the Manufacturers' LNG Technical Subcomittee of the Alternative

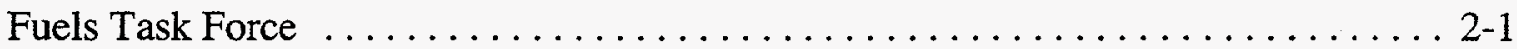

Appendix 3: Trucking Research Institute Alternative Fuel Demonstration Projects, Project

Contact Names . ........................... 3-1 


\section{Introduction}

This report details the activities of the Trucking Research Institute (TRI) in support of the National Renewable Energy Laboratory's (NREL) work as field manager to implement Section 400BB of the Alternative Motor Fuels Act of 1988 (AMFA). That Act's purpose was to "Amend the Motor Vehicle Cost Savings Act to provide for the appropriate treatment of methanol and ethanol and for other purposes." ${ }^{11}$ Section $400 \mathrm{~B}$, which contains provision relating to trucks, is very brief, and establishes an Alternative Fuels Truck Commercial Application Program. It reads,

"ESTABLISHMENT. -- The Secretary, in cooperation with manufacturers of heavy duty engines and with other federal agencies, shall establish a commercial application program to study the use of alcohol and natural gas in heavy duty trucks and, if appropriate, other heavy duty applications."

The program was initially authorized a total of $\$ 4,000,000$ for each of the fiscal years 1989 , 1990, and 1991.

Nearly concurrent with the passage of AMFA, the ATA Foundation, which is the research and public outreach arm of the American Trucking Association, recognized the future importance of alternative fuels to the commercial trucking industry ${ }^{2}$. Heavy-duty trucking depends almost solely on diesel fuel to move the nation's freight. Disruption of that fuel's supply for any reason or a mandate to use some other fuel would seriously affect the industry. Most of the debate that might force a mandate for alternative fuels centered on potential air quality benefits, but ignored the economic, operational, health, and safety effects of introducing alternative fuels into trucking. Consequently, the industry directed that the ATA Foundation conduct an industry-funded study of these effects. The Battelle Memorial Institute carried out the industry study ${ }^{3}$ in 1989-1990, and published it in April 1991. It assessed the impact of the five alternative fuels thought at the time to be those most likely to replace conventional fuels, namely, M100 (neat methanol), M85 ( $85 \%$ methanol and $15 \%$ gasoline), CNG (compressed natural gas), LPG (liquefied propane gas, or propane), and LNG (liquefied natural gas). These fuels would presumably be introduced into the five geographic regions most likely to mandate alternative fuels: Denver, Boston, Chicago, Los Angeles, and Houston. Probably the most significant lesson learned from that study was that there was little real knowledge about using alternative fuels in trucks, because there were no meaningful instances of their actual use by trucks.

Public Law 100-494, enacted by the 100th Congress on October 14, 1988.

For purposes of this report, the term "trucking industry" is taken to mean motor carriers, both "for hire" and private carriers, suppliers to carriers, e.g. truck chassis original equipment manufacturers (OEMs), engine manufacturers, component suppliers for such items as transmissions, tanks, axles, etc., and interested service firms, such as insurance, electronics, and communications companies with motor carrier markets. 
That lack of knowledge led TRI to enter into a partnership with the U.S. Department of Energy (DOE) to create demonstrations of alternative fuels in commercial truck operations. That effort was the impetus for the contract between NREL and TRI-a partnership between industry and government to advance the knowledge about using alternative fuels in commercial trucking. This is the final report on the initial work of that partnership.

\section{Project Overview}

\section{Objectives}

The principal objective of the project was to understand the effects of using an alternative fuel on a truck operating fleet through actual operation of trucks. Information to be gathered was expected to be anecdotal, as opposed to statistically viable, because TRI recognized that projects could not attract enough trucks to produce statistically credible volumes of data. TRI was to collect operational data, and provide them to NREL, who would enter the data into the alternative fuels database being constructed for heavy-duty trucks at the time. NREL would also perform data analysis, with the understanding that the demonstrations were generally pre-production model engines and vehicles.

Other objectives included providing information to the trucking industry on the availability of alternative fuels, developing the alternative fuels marketplace, and providing information on experience with alternative fuels. In addition to providing information to the trucking industry, an objective was for TRI to inform NREL and DOE about the industry, and give feedback on the response of the industry to developments in alternative fuels in trucking.

At the outset, only small numbers of vehicles participated in most of the projects. Therefore, they had to be considered demonstrations of feasibility, rather than data gathering tests from which statistically significant conclusions might be drawn. Consequently, data gathered were expected to be useful for making estimates and obtaining valuable practical lessons. Project data and lessons learned are the subjects of separate project reports. This report concerns itself with the work of TRI in meeting the overall objectives of the TRI-NREL partnership.

\section{Approach}

TRI took a multi-faceted approach to the project objectives. To achieve the first objective, TRI identied fleets that were willing and able to test an alternative fuel, and carried out a "brokerage" function by bringing together fleet users, vehicle engine and fuel suppliers, and other participants who would help sponsor the project either financially or through in-kind service. TRI deemed it essential that before beginning any new demonstrations of alternative fuel trucks, a thorough survey of current uses be conducted and used as a starting point for identifying fleets that might be interested in pursuing further demonstrations. Moreover, at the outset, NREL identified several constraints that apply to all projects funded under this work: 
- $\quad$ All vehicles and engines must be OEM products, not conversions.

- Funds were not available for infrastructure or fuel differential costs. Only vehicle and engine differential costs could be covered.

- Projects should be 3 years in duration, although funding might be incremental because of annual federal budget cycles.

- $\quad$ No preference would be given to any fuel; that is, projects would be "fuel neutral," and market forces would be permitted to operate to the greatest extent possible. One of the most burning questions regarding alternative fuels, especially in the early 1990s, was "Which fuel?" This guideline was meant to elicit the answer to that question.

TRI agreed to conduct a fleet survey, prepare a report as a deliverable, and update its list periodically from the fleets surveyed, or found by other means. TRI also submitted recommendations to NREL about the fleets with the greatest promise of accomplishing a project using a particular fuel. TRI also provided whatever data were available from user fleets; however, it quickly became apparent that few useful data were available because fleets using alternative fuels had not been collected specific data on these trucks.

With respect to the task to provide information to the industry, TRI chose to produce and distribute a quarterly newsletter, Alternative Fuels in Trucking. TRI and NREL collectively created a distribution list for the publication, and over time, that list grew as more people, both within and outside the trucking industry, became interested in its content.

Finally, to provide dialogue on the subject of alternative fuels, TRI, through its parent organization, the ATA Foundation, established the Alternative Fuels Task Force, which, as with other such task forces managed by the Foundation, consists of senior executives of trucking industry members, government officials, interested parties from consulting firms and so forth. The purpose of the Task Force is twofold-first, to provide a regular meeting venue for the ATA Foundation to brief Task Force members and keep them updated on our activities relative to alternative fuels; and second, to listen to their concerns relative to the topic, and tailor ATA Foundation activities to respond to those concerns. The Task Force structure also allows subgroups of industry experts to be formed from member companies of the industry. For instance, as will be described later, the Task Force was the source of company engineering expertise needed to develop the Society of Automotive Engineers (SAE) Recommended Practice for LNG Heavy-Duty Trucks. Task Force executives provided qualified people from their companies to perform the work. The Task Force system has been in use for many years, and provides the membership of the ATA Foundation a comfortable environment to conduct discussions with government officials, and, perhaps most importantly, is a recognized system for companies engaged in competitive activity to meet with anti-trust protection afforded by the status of the trade association's legal position. Meetings are regularly scheduled three times per year, and are carried out in strict accord with anti-trust guidelines. 


\section{Narrative History of Program Development}

\section{Midwest Ethanol Project}

In the summer of 1992, at the beginning of this project, only four fuels could practically be used in trucking operations: ethanol, methanol, natural gas (compressed only), and propane. In order to set up a project using one of these fuels, TRI had to find a target fleet, obtain a suitable truckengine combination, and arrange funding for the non-truck/engine differential costs. Surprisingly, even though at the time a number of companies used propane for city delivery, it was not possible (then or ever, as it developed) to find any fleet willing to use propane, despite the presence in the marketplace of at least one OEM truck available for that use, the Ford F-700. In fact, given the constraints established, the first project that was actually feasible was the Midwest Ethanol Project, because it was the only combination of fleets, fuel suppliers, and engine and chassis manufacturers available and willing to carry out the work. Additionally, the real impetus for this project came from the Midwest users themselves, led by Hennepin County's manager of Administrative Services. At the outset, three jurisdictions wished to participate. Each agreed to bear the differential costs of fuel and infrastructure, and to collect and report data on the demonstration in return for financial support to bear the differential vehicle and engine costs. The Nebraska Department of Roads and the Iowa State Transportation Department also expressed interest in the project.

\section{Difficulties with the Midwest Ethanol Project and their Resolution}

Difficulties in setting up the Midwest Ethanol Project arose in several areas. The first was funding, but not for the ethanol vehicles. Instead, it involved the diesel control vehicles that were integral to the demonstration. Only one engine, the Detroit Diesel 6V92, enjoyed the necessary EPA certification for vehicular use. It is principally a bus engine, and only two truck chassis models, the Navistar "Paystar 5000" and the Volvo-GM "Autocar," had been design-engineered to accept that engine. No other OEM was willing to perform that engineering design work because of its cost (we were told it costs nearly $\$ 1$ million), and the absence of any market in trucking for the $6 \mathrm{~V} 92$. The financial difficulty arose because none of the cooperating fleets used either vehicle in its fleet, and both were substantially more expensive than their normal fleet vehicles. Because the NREL money could not be used for the differential cost of the diesel control vehicle, which came to more than $\$ 20 \mathrm{~K}$, the participants needed to raise that money themselves. The State of Iowa was unable to do so, and dropped out of the project. Nebraska was also unable to obtain the money, but Hennepin County received authorization to make the purchase. In the interest of gathering broader information, NREL and TRI agreed that the Hennepin County diesel control vehicle would satisfy that requirement for the Nebraska project, and Nebraska was relieved of the requirement to obtain or use a diesel control truck. This workaround was deemed acceptable because of the basic similarity in the vehicles' duty cycles (snow plowing during the winter and maintaining roads during the non-snow seasons). The vehicle chassis chosen, because of the price, was the Navistar Paystar 5000. 
The next difficulty arose because it could only be factory-produced with the mechanical version of the diesel 6V92, which is not certified by EPA for on-highway use. But because Navistar would not agree to build the chassis as a "glider kit," (i.e., a chassis with all components except the engine), the trucks had to be built with the mechanical engine installed. Consequently, the 6V92 ethanol and diesel certified engines were pre-delivered to a Minneapolis Detroit Diesel Corporation (DDC) distributor, Interstate Detroit Diesel, who took delivery of the vehicles and repowered them with the $6 \mathrm{~V} 92$ ethanol and electronically controlled diesel engines. The dealer also removed the mechanical diesel engines and sold them for credit. Because of these equipment expenditures, the government was required to maintain ownership of the engines, and NREL entered into separate agreements with Hennepin County and the Nebraska Department of Roads to enable proper accounting of them for 7 years. Those agreements are still in force, although Hennepin County has requested that they be terminated.

The third difficulty arose from the need for infrastructure, specifically tank storage and dispensing, for the ethanol. The users feared that the ethanol would not store well in ordinary tanks because of the potential for corrosion and for weather-induced condensation. DDC provided a fuel specification, and Hennepin County ascertained that it possessed an underground tank that could be cleaned and maintained so the fuel would not become contaminated. To ensure fuel purity, Nebraska purchased a dedicated 1,000-gallon tank for storing the E85.

Lastly, both sites required separate funding support for the price differential between neat ethanol and diesel. Because of the lesser energy content of ethanol, this was a considerable difference. Hennepin County obtained some relief from Archer Daniels Midland Company at the beginning of the project. Nebraska's Energy Department came to the aid of the Department of Roads by funding not only some of the fuel differential, but the total of the cost differential of the ethanolpowered vehicle over its normal fleet vehicle, which was substantially less.

Because of the setup difficulties encountered, the first Midwest Ethanol Project contract was not consummated until April 1993, when the vehicles were ordered, even though the NREL-TRI contract was scheduled to begin in July 1991. The project actually began in Hennepin County in November 1993. Nebraska's trucks entered service in September 1994. The vehicle specifications for the Midwest Ethanol Project are in Appendix 1 to this report.

\section{The UPS Package Delivery Vehicle Project}

TRI entered into discussions in early 1993 with United Parcel Service (UPS), which was interested in powering a portion of its package car fleet with CNG engines manufactured by the Tecogen company. ${ }^{4}$ This company had entered into an agreement with General Motors (GM) to modify the GM 4.3L gasoline engine used in the P-80 series UPS package cars to allow it to use natural gas as fuel. Modifications included alterations to internal components to allow a greater

\footnotetext{
4 Tecogen is a subsidiary of Thermo Power Corporation. The engines were actually produced by a sister subsidiary, Crusader Engine.
} 
compression ratio, an advanced fuel system, and closed loop electronic controls. Until this time, all of UPS's natural gas vehicles operated on gasoline engines that had been converted to use natural gas. This was the first use of a factory-built dedicated engine designed initially to use only natural gas. Further, UPS was in discussions with Washington Gas Company to provide a natural gas fueling facility at the UPS terminal in Landover, Maryland, a suburb of Washington, D.C.

Although the project would involve repowered vehicles rather than OEM factory-manufactured ones, NREL considered this project to have sufficient merit to warrant its support, especially since UPS's package cars are proprietary vehicles, manufactured especially for that company, and not sold commercially to other customers. Moreover, UPS keeps them in service for decades. The benefits of testing CNG in a fleet as important as UPS outweighed the disadvantage of using repowered vehicles. NREL funding covered only the cost of the 20 Tecogen engines and their installation costs; UPS bore the cost of CNG fueling systems on the vehicles.

\section{Difficulties with the UPS Project and their Resolution}

The only significant difficulties encountered in setting up the UPS project arose from delays in contracting. With UPS, as with the Midwest Ethanol Project, the issue of government ownership of the engines was part of the contracting process. Therefore, a separate agreement between UPS and NREL was necessary to account for the technical inventory and accountability of the engines. These difficulties were surmounted through the combined contract negotiating skills of the NREL Contracting Section and the UPS Headquarters.

Once the project was contracted, UPS managed the process of ordering and installing the engines. For this purpose, UPS used a local Washington, D.C. metro area subcontractor, American Ecofuels, Inc., of Chantilly, Virginia. The installations took several months, and as vehicles were repowered, they were delivered to UPS. UPS waited until all vehicles were in place before beginning data collection, because its maintenance data collection system was being changed throughout the company at that time, and the company wanted to avoid data differences that might arise from the transition. As NREL and UPS had agreed before the project, UPS was allowed to use its own data collection system rather than the system in use for other projects.

UPS experienced minor engine difficulties at the outset of the project, but worked these out with American Ecofuels, and the staff underwent the necessary training to enable them to safely and properly work on the vehicles. Ultimately, after about the first 90 days of fleet operations, UPS assumed all repair and maintenance matters on the vehicles, integrating them totally into its local fleet. Throughout the project, the vehicles, with one exception, experienced essentially equivalent operation with their gasoline counterparts. The exception was a single engine that experienced catastrophic failure two-thirds of the way through the project. UPS removed that engine and substituted it with another natural gas engine. As a contracting matter, then, NREL took steps to survey the engine and have its federal ownership abandoned. UPS and NREL resolved this matter between them. 


\section{The AG Processing Biodiesel Project}

Biodiesel is a methyl-ester product of certain types of crops such as soy and rapeseed. It is called biodiesel because it has the ability to burn in a compression ignition engine. It is desirable as an alternative fuel because it is derived from crops and other renewable sources, such as used cooking oil, and because carbon monoxide, hydrocarbon, and particulate matter emissions from burning it in diesel engines are lower than those of No. \#2 distillate oil (diesel fuel) combustion.

In March 1994, the National Soy Diesel Development Board asked TRI to investigate the feasibility of conducting a demonstration project in which biodiesel fuel would be tested in trucking operations involving long-haul trucking of agricultural products in the Nebraska-South Dakota region. A host fleet was proposed. AG Processing, a company whose business involves agricultural products hauling, had a large fleet from which three sets of three vehicles (each with tthe same heavy-duty engine/chassis combination) could be operated with biodiesel blended fuel and compared to fossil diesel fuel.

Setting up this project required some exceptions to the NREL guidelines for the projects, specifically that fuel differential costs were not expected to be funded. Moreover, because the biodiesel blend suggested was $35 \%$ biodiesel $/ 65 \%$ diesel, an exception to consider this an alternative fuel was required from DOE. NREL agreed to use project money to reimburse AG Processing for the differential fuel cost, and DOE's director of the Alternative Fuels Utilization Division granted permission to consider 35/65 biodiesel blend an alternative fuel for demonstration purposes in this project.

AG Processing trucks began operating in January 1995. During the first 2 years of the project, some participating trucks were retired from service and replaced with newer models. The full list of vehicles used in the project is included in Appendix 1.

\section{Difficulties with the AG Processing Project and their Resolution}

Once the necessary exceptions to guidelines were obtained, it was quite simple to set up this project because it involved only minor mechanical changes. All vehicles were provided with new injectors at the beginning, and the fuel storage and pumping facility at AGP was separated so biodiesel was available at one pump and conventional diesel at the other. The fuel storage tanks are above ground, and the fuel inlet piping is at the bottom of the tanks. The blending process involved first loading biodiesel into its tank, then adding conventional diesel to mix the product. The final contract was executed in November 1994, and the vehicles began operating in January 1995.

During the course of the project, the most significant difficulties encountered were in operating the trucks on biodiesel blend during cold weather. In January, February, and March 1995, weather conditions caused the 35/65 blend fuel to gel, which presented cold-starting problems. This, in turn, necessitated either keeping the vehicles indoors at night, or letting the engines run all night, both highly undesirable solutions. The gelling was alleviated somewhat by using No. 1 
diesel (kerosene) as a substitute for No. 2 diesel in the blend, but this resulted in lost mileage and power. Even with the No. 1 diesel, on the coldest nights (below $20^{\circ} \mathrm{F}$ ), the engines had to run overnight. Additionally, fuel in the storage tank gelled in very cold weather, and the project suffered for a time because of these combined effects.

To surmount the difficulties encountered during the first winter, a multifaceted approach was used. This involved installing a submersible heater into the biodiesel storage tank to keep the blended fuel above $45^{\circ} \mathrm{F}$, and adding a circulating pump to ensure frequent mixing of the blend. The pump was set to operate for 20 minutes daily. For the trucks, the fix varied with the type of engine involved. For non-electronic engines, Cummins NTC 315 and 350, fuel on board is heated with an in-tank heater. In electronic engines, DDC 60 and Cummins M-11, a large volume of fuel flows by the fuel injectors to remove engine combustion heat. This heated fuel is returned to the tank. These fuel heating measures were augmented by installing blanket type heaters on the fuel tanks to ensure that the fuel was kept warm while the trucks were shut down. Once engines were started and brought to running temperature, the tank heating blankets shut down. Additional funds to make the storage tank and tank heating blankets were added to the project, but these funds were well spent, because during the winter after the modifications were made, trucks operated satisfactorily and the fuel did not gel, despite temperatures as low as $-20^{\circ} \mathrm{F}$.

\section{The Los Angeles Times Project}

Perhaps the least complicated project undertaken in the TRI-NREL partnership was the project in which the Los Angeles Times acted as host for one of the first DDC Series 60 natural gas heavyduty engines. The DDC Series 60 diesel is one of the most successful and widely used heavyduty truck engines, and in 1994 DDC was eager to develop a natural gas version to fill a need for a low-emission, heavy-duty, high-horsepower engine that could successfully compete in overthe-road trucking operations, particularly in California. The Acurex Environmental Corporation of Mountain View, California, had worked with a number of agencies in that state to bring together funds, fuel suppliers, and host fleets to test prototype heavy-duty natural gas engines. Several DDC Series 60 s were among these prototypes. NREL wished to become a participant in this work. TRI entered into a lower tier subcontract with Acurex to facilitate NREL's participation in the project. NREL, TRI, and Acurex agreed that all data collection and reporting on the project would be the responsibility of Acurex. Acurex was under contract with the South Coast Air Quality Management District (SCAQMD) to conduct a multi-vehicle fleet demonstration, and the final report of that activity contains all details of the Los Angeles Times truck operations.

In summary, however, by the end of the project, in which several DDC S60G engines were involved, DDC's initial enthusiasm for the natural gas version of the Series 60 had waned considerably. DDC now plans to make the engine available for motor coach use only, and will not make it available for use in trucks unless a stronger market develops. 
The final report of this portion of the TRI-NREL Partnership as it relates to this contract is contained in an Acurex report. ${ }^{5}$

\section{The Chambers Development Project}

Perhaps the most significant of all projects undertaken by TRI during the course of the work under this contract has been the project to run trash haulers at Chambers Development Company ${ }^{6}$ in Washington, Pennsylvania. There are several reasons for this. First, it is the first and only project that began with the expectation of using enough trucks (seven) to allow data gathering that would have statistical significance. Second, the project sponsors, particularly the private ones, demanded that the project push the envelope of available technology. In other words, this project envisioned commercially ready vehicles and a fueling facility that was planned to be a permanent infrastructure. It was initially owned by the sponsors, who planned to sell it to the host fleet at the end of the 3-year data-gathering phase. The sponsors specifically declined to use a temporary fueling facility to start the project. Third, the project envisioned an integrated vehicle-infrastructure system. Finally, this project more than any other led to the development of the SAE Recommended Practice for LNG Powered Heavy-Duty Trucks?. This is an industryaccepted document that provides guidance to manufacturers, suppliers, and users of LNG trucks

Alternative Fueled Truck Demonstration: Natural Gas Program Final Report, submitted by Acurex Environmental Corporation, Mountain View CA, March 21, 1997, Acurex Environmental Final Report FR97-101.

Chambers Development Company no longer exists. In 1996, the company was purchased by USA-Waste Corporation, the nation's third largest waste processing company. USA Waste is the owner of the LNGpowered vehicles, but it has delegated execution of the project to its subsidiary in Washington, Pennsylvania.

That company is the William H. Martin Company. For simplicity, the project will be referred to throughout this report as the Chambers Project.

SAE international publication: Surface Vehicle Standard. Recommended Practices for LNG-Powered Heavy-Duty Trucks (SAE J2343), issued January 1997. 
to enable them to design, operate, and maintain these vehicles safely and efficiently. How this recommended practice came into existence and its importance is discussed later in this report.

In late 1992, TRI brought together several companies with an interest in creating a truck project using LNG fuel. Those companies, collectively called "The LNG Consortium," were Columbia Gas of Ohio, Consolidated Natural Gas, Equitable Gas Company, Mack Trucks Inc., and Chambers Development Company. Each of the three gas distribution companies provided service in the greater Pittsburgh area, which includes Washington, Pennsylvania. Chambers provided refuse service in the area, and Mack was Chambers' preferred vehicle manufacturer. Chambers was interested in exploring the use of environmentally cleaner fuels and agreed to host a fleet of as many as seven natural gas trash haulers. Mack was conducting the first test of its E7 heavyduty engine powered by natural gas, and had a hauling operation that used a CNG-powered truck operated by BFI in Boston. The company was eager to make second generation improvements to the E-7 to bring it to commercial readiness, and the gas companies were interested in developing a fuel market for $\mathrm{LNG}$ in the Pittsburgh region. Each of the gas companies agreed to provide $\$ 200 \mathrm{~K}$ to a fund that would be used to keep Chambers "whole" by paying for the differentialcosts of engines, vehicles, fuel, and the fueling station. TRI agreed to act as project coordinator, and attempt to bring enough additional money to the project to get it started. Mack and Chambers agreed to contribute substantial time in research and planning to ensure the project's success. All parties entered into an agreement to codify the responsibilities of each participant. TRI consented to create such an agreement. The three contributing gas companies adamantly insisted that the project be structured so as to avoid pitfalls encountered other LNG projects. These pitfalls occurred because of attempts to use "off-the-shelf" equipment cobbled together to make a fueling station or convert a vehicle to LNG from diesel.

TRI immediately suggested the project to NREL, and began negotiations to secure funding under the NREL-TRI partnership. This project embodied all the guidance of NREL in its work with TRI, but because of the constraint on NREL funding fuel or infrastructure, it could not be supported until all necessary funding for those items had been pledged. TRI agreed to find enough funding to complete the project, and, with the agreement of the non-government members of the consortium, began take the necessary steps to ensure that the project would be ready for launch when funding had been secured.

\section{Difficulties with the Chambers Project and their Resolution}

Finding and Retaining Funding. Before describing the difficulties encountered and steps taken to overcome them, it is important to note that many of the events described in this section took place concurrently. The greatest difficulty encountered involved finding funding and retaining it long enough to complete the setup of the project. In the course of setting up the agreement among the several founding members of the consortium, one company, Equitable Gas, after agreeing throughout the process to the terms of the agreement, changed its corporate strategy to support only CNG-related projects. Once that change was made, Equitable Gas removed its support for the Chambers project. Next, Chambers Development withdrew from the project because of financial difficulties. To overcome the loss of Equitable, TRI persuaded Columbia to make two 
annual payments in advance. Despite attempts to enlist another fleet (both BFI and Waste Management - WMX Corporation were approached), none could be found. By fortunate circumstance, enough time elapsed as a result of other delays, that Chambers agreed to return as host fleet shortly before being sold to USA Waste.

Ultimately, money to replace the loss of Equitable was secured by obtaining a grant for $\$ 344 \mathrm{~K}$ from the Pennsylvania Energy Office, which later was absorbed into the Commonwealth's Department of Environmental Protection. No sooner was that funding loss overcome, when Consolidated Natural Gas withdrew its support, citing corporate restructuring, in which the company shed itself of all research activities. Since it had already paid one-third of its pledge, its loss was somewhat less significant. TRI was able to secure replacement funding from GRI and Pacific Gas and Electric Company of California. Both of these entities desired to support, and derive information from, the LNG fueling station being produced at Chambers. Just as the project was actually inaugurated, in July 1997, Columbia Gas also reorganized, and divested itself of all research activities. Consequently, it no longer desires any data from the project.

Ensuring System Compatibility. Another significant difficulty encountered was ensuring system compatibility between the truck LNG fuel system and the station. The approach to this challenge was to engage in a bidding process in which cryogenic suppliers were solicited to undertake the project as a system, that is, to require them to bid the entire vehicle-station system. Several companies were solicited. These were, Minnesota Valley Engineering (MVE), CVI, Chicago Bridge and Iron, Cryenco, and Drexel. Two finalists, MVE and CVI, made second presentations, and finally CVI of Columbus, Ohio was chosen. It began the design phase of the project, working closely with Mack and Southwest Research Institute (SwRI), which was Mack's engine and fuel system subcontractor. Their work was interrupted, however, by the withdrawal of Chambers noted earlier.

Work began again in 1996, after Chambers agreed to return to the project. To assure truck system safety, durability and functionality, CVI provided Mack with a set of vehicle tanks for testing. The first two sets of tanks failed the rigorous Mack tests, which involved subjecting the tanks to several hundred thousand cycles of bumps, and the vehicle tanks had to be redesigned. The third set of tanks passed the Mack testing. CVI determined, however, that the redesigned tanks were considerably more costly than the originally bid tanks. As a result of this suggested cost increase, Mack decided to choose another supplier, and selected tank manufacturer MVE, whose tanks were subjected to the same testing, passed, and were supplied for the project. This change in truck tank manufacturer necessitated coordination between MVE and CVI to ensure that stationvehicle fuel system compatibility was achieved. Fortunately, this compatibility was easily achieved, and the project achieved this major goal of assuring system compatibility.

Ensuring Safety Compliance and Establishing an Industry Standard. Concurrent with the fuel system development being done for Mack by SwRI, the National Fire Protection Association (NFPA) was formulating its regulation for LNG-powered vehicles, NFPA-57. SwRI, at Mack's request, reviewed the draft NFPA-57 in November 1993, and reported that if the draft were 
approved, OEM compliance would be so costly that LNG trucks would be unaffordable. To preclude this, TRI arranged a meeting with committee members of NFPA who were working on the draft standard NFPA-57. That meeting took place in Akron, Ohio, in November 1993, and led to an agreement that the NFPA Committee would review suggested changes to the proposed standard, and that those suggested changes would be provided by SwRI. The proposed changes were to be reviewed in time for the committee's scheduled meeting in April 1994, but this delay occurred because the NFPA organization experienced internal disagreement on jurisdiction over LNG powered trucks, and it took nearly a year to resolve these issues. In the meantime, SwRI continued design and testing of the E7 engine and chassis mounting issues for the LNG powered refuse hauler.

The most significant outcome of the discussions with NFPA was that Mack declared that it did not intend to produce production heavy-duty LNG-powered trucks without some assurance that such vehicles would be consonant with some sort of industry standard. NFPA, which is not a normal standard setting agency for the automotive industry, was not moving ahead with NFPA57, so TRI proposed to set up a subcommittee of the Alternative Fuels Task Force. Its objective was to create an industry-accepted standard for such vehicles. NREL agreed that such activity would be worthwhile, and agreed that it be done under this contract. TRI set up the Manufacturers' LNG Technical Subcommittee of the Alternative Fuels Task Force.

Subcommittee makeup is given in Appendix 4 of this report, along with a listing of the most pertinent regulations and rules reviewed as part of the process of creating the industry standard. The subcommittee includes representatives of the industries involved in producing, operating, or maintaining a truck powered by LNG. TRI, as a charitable trust industry trade association, enabled the group to ensure compliance with national anti-trust laws and regulations that apply to these activities.

Overcoming the difficulties posed by the absence of any kind of industry practice for manufacturing, operating, and maintaining LNG-powered heavy-duty trucks proved to be an exceptionally complex and time-consuming task. This was formally begun in Spring 1994. TRI's approach, after establishing the technical subcommittee, was to begin by conducting a Failure Modes and Effects Analysis (FMEA). For this activity, TRI engaged the services of the nationally renowned engineering firm, Failure Analysis Associates. This firm facilitated the FMEA during several meetings with the subcommittee, and in so doing, produced a working document that served as the basis for an industry recommended practice. The subcommittee membership created this document from Fall 1994 through Winter 1996. TRI administered the process, which consisted of approximately quarterly meetings with the subcommittee. During this time, the FMEA was used as the basis for producing several drafts of an SAE recommended practice. At each meeting, subcommittee members took up each draft and made suggested changes to ensure that agreeable language was included. Also, subcommittee members reviewed laws, regulations, other industry standards, and practices and local regulations to ensure that reference and account of these were made in the SAE document. In several instances, while the recommended practice was being produced, TRI communicated with other standard-setting agencies with similar interests in LNG-powered vehicles, and ensured that they were apprised of our work. TRI also made sure that the proposed recommended practice was consonant with their 
suggested regulations. As a result of these consultations, the NFPA-57 Standard contained a technical correction that made it consonant with SAE J2343, the ultimate output product of the subcommittee's work. Also included in consultation was the Railroad Commission of Texas, whose LNG regulations include input from the SAE process. Similar consultation is under way now with the California Highway Patrol, which is revising its state's Title 13, which contains regulations for $\mathrm{LNG}$-powered vehicles.

Once the subcommittee members reached tentative agreement on language for the recommended practice, it was sent out for a vote by SAE. That vote brought several comments and suggested further changes. TRI chaired additional meetings to address each comment and achieve resolution, after which a revised version of the document was sent out by SAE for another vote. On the second ballot complete consensus was reached, and the document was approved for publication. SAE J2343, Recommended Practice for LNG Powered Heavy-Duty Trucks is available from the Society of Automotive Engineers (www.sae.org).

\section{Con-Way Western Express Project}

One of the key early outcomes of the TRI-NREL partnership in assessing the use of alternative fuels in commercial trucking operations has been the conclusion from the initial projects that LNG has the greatest likelihood of competing with diesel fuel on a cost of operations basis. This realization fueled interest of the participants in the Manufacturers' LNG Technical Subcommittee described above, and that stimulated desire on the part of manufacturers-chassis OEMs as well as engine and component suppliers - in putting vehicles on the road to field test their new products.

This being the case, TRI began focusing its attention on LNG, and tried to find fleets willing to host LNG demonstrations. Three such fleets were located, and TRI recommended that each be enlisted to conduct a LNG demonstration of a particular vehicle-engine combination. The first of these, found in 1994, was the Con-Way Transportation Company, a less-than-truckload (LTL) company with fleet operations throughout the country. Con-Way wished to conduct a project that married the Cummins C (8.3L) engine with the Ford L8000 chassis. The operators use many such vehicles as part of its "city delivery" duty cycle. Con-Way was, at the time, a non-union subsidiary of Consolidated Freightways (CF), one of the nation's largest LTL carriers. ${ }^{8}$ This fleet wished to put the LNG trucks in operation in the greater Los Angeles area as part of a corporate strategy of enhancing its environmental image. It also wanted LNG as a possible substitute for diesel because of potential regulations that would restrict diesel trucks in that area. CF chose its

Con-Way and CF split in 1996. For reference, LTL motor carriers operate by consolidating several shipments into a single van, and transport these shipments between terminals in a classic "hub and spoke" operation. Included in the operation is a segment that picks up and delivers individual shipments throughout major urban areas. This contrasts with Truckload (TL) operations, in which a single van is loaded with the goods of a single shipper, and is moved "over-the-road" from origin to destination. LTL operators customarily have their own fueling facilities, and operate between fixed terminals on regularly established routes. 
California-based subsidiary, Con-Way Western Express, as the host fleet for the trial. NREL agreed with TRI's recommendation to pursue the Con-Way project because it epitomized the guidelines: OEM vehicle, dedicated engine, system engineered LNG fuel system, and appropriate fleet user. TRI established a working group to set up the project, and held meetings both at Cummins Engine Company and the MVE tank manufacturing plant in Canton, Georgia. This latter meeting resulted from the first, because the parties to the project were all interested in seeing how cryogenic tanks were manufactured, and in learning more about that supplier.

\section{Difficulties Encountered with the Con-Way Project and their Resolution}

The Con-Way project proceeded smoothly at the outset, largely because the companies involved had very specific conditions to be followed. Con-Way specified exactly which chassis-enginetank combination it required. Ford selected a local Detroit engineering firm, Modern Engineering, to install the fuel system, and ensured that the installation would be observed by Ford engineers. Ford specified that the fueling system's architecture be recorded so that future LNG vehicles would conform. Cummins and MVE worked cooperatively to ensure that the LNG fuel system was prepared for certification by the California Air Resources Board (CARB). Because the engines involved were field test versions, Cummins entered into a separate field test contract with Con-Way, and obtained the necessary waivers from CARB to operate the trucks in California before certifying the engine.

The vehicles were ready to enter service in December 1995. At the time they were to be delivered, Con-Way notified TRI that it did not wish to execute the lower-tier subcontract with TRI because the company had no contracts with the federal government, and did not wish to undertake the necessary corporate administrative changes. Con-Way did agree to provide data, however, and TRI arranged with Acurex Environmental to act as liaison for collecting the data, much the same as with the Los Angeles Times project. Fueling for the vehicles was to be done at the Mesa Olympic LNG facility in downtown Los Angeles, near the terminal where the two vehicles were to be based.

For the first several months, the vehicles operated more or less satisfactorily, but by Summer, had experienced driveability difficulties to the extent that Con-Way turned one of the vehicles back to Cummins Cal-Pacific, the local Cummins distributor, which had it shipped back to Indiana for substantial rework of the engine control system. The difficulties were attributed to the fact that the Con-Way trucks were the only Cummins $C$ engines in their field test group with manual transmissions. As a result, they had been designed and calibrated the same as the others, and took into account many parasitic loads associated with automatic transmissions. This resulted in stalling and rough idling, which Con-Way found unacceptable. This vehicle remained in Columbus, Indiana, with the Cummins test facility until early 1997, when it was shipped back to Cummins Cal Pacific with corrected calibration. This new calibration was installed on the second vehicle as well. 
While the first vehicle was in Indiana, the second vehicle developed problems with the installed methane detection system, which alarmed erratically. This system needed recalibration, which proved difficult because Modern Engineering had procured it from TDM Technologies of Livonia, Michigan, which had ceased dealing in the methane detectors. After considerable difficulty, Cummins Cal-Pacific was able to acquire the correct calibration gas test kit, and recalibrated the methane detectors so they operated correctly.

In the intervening time, from Summer 1996 to early 1997, the Con-Way vehicles were idle. In addition to the difficulties experienced with the driveability and methane detection, the fueling facility where they had been refueled was going out of business. It was kept in operation by Acurex Environmental and SCAQMD, but despite this, Con-Way did not want to use that facility because it required a good deal of advance planning to pre-cool the station before trucks could be fueled. Con-Way wanted to move the vehicles to their terminal in Rialto so it could train a new cadre of drivers, and operate the vehicles at the facility closest to its local headquarters.

This desire led to the decision to fuel the vehicles at a new LNG station to be constructed in nearby Ontario, Canada. This station was to be constructed at a UPS facility, and be made in such a way that an off-property dispenser was available for non-UPS vehicles. Unfortunately, the station's permitting process was fraught with difficulties. The company that contracted to do the work, ALT-Jack B. Kelley, and its subcontractor, Cryenco, did not follow procedures to the satisfaction of city of officials, and the permits, which were applied for in late 1996, were not actually received until mid-1997. Immediately following final approval of construction, the process was held up by the strike against UPS, which precluded union contractors from working on the UPS site. That problem was solved with the strike's settlement in late August, and the station is now expected to begin operation in February 1998.

Meanwhile, Acurex and TRI attempted to persuade Amoco, which operates a LNG fueling facility at a nearby terminal owned by Perrier Water, to obtain permission for the Con-Way vehicles to refuel there. That proved difficult because Perrier, despite the expectation that they would make the station available to non-company vehicles (because it was partially paid for by public funds from SCAQMD) raised objections. Negotiations between Perrier and Amoco are still underway to enable non-Perrier trucks to refuel at the station.

\section{The Liquid Carbonic-Praxair Project}

Liquid Carbonic is a large cryogenic chemical products company. Its product line includes all forms of cryogenic industrial products, including carbon dioxide, argon, and liquefied methane (LNG). In the early nineties, Liquid Carbonic decided to pursue the LNG transportation market in a major way, and constructed a multimillion dollar plant in Willis, Texas, near Houston. The Willis LNG plant was devoted to producing very high purity liquid methane, $99.5 \%$ pure, for use in transportation. It was specifically aimed at the heavy-duty engine market, first buses, and later to include trucks. Liquid Carbonic engaged in a significant marketing effort to convince engine manufacturers and users of LNG vehicles that $99.5 \%$ pure methane "transportation-grade LNG" 
was the safest and most effective type of fuel. Other companies considering marketing LNG, such as natural gas service companies with large LNG "peak shaving" plants, opposed this strategy. These plants produce liquefied natural gas, the composition of which varied in methane content as a function of both time and location. ${ }^{9}$ Engine manufacturers, recognizing the variance in natural gas content, have constructed and programmed their engines to run satisfactorily on natural gas with methane content on the order of $92 \%$, with reasonable specifications for other constituents.

The issue of fuel composition was actively debated during the process of creating the SAE Recommended Practice for LNG-powered trucks, and ultimately resolved by leaving the responsibility for fuel content specification to the discretion of the engine manufacturers, as they ultimately bear the responsibility for the engine's performance. Their ability to produce engines that would operate satisfactorily at methane purity less than $99.5 \%$ created, indirectly, a competitive disadvantage for Liquid Carbonic, because its high purity fuel was more costly than lesser grade LNG.

The fuel composition resolution had not been reached in mid-1994 when Liquid Carbonic leased five LNG-powered heavy-duty trucks from Ruan Company, a major truck leasing company.

Liquid Carbonic assigned these trucks, which combined the DDC S60G engine with a Freightliner chassis, to the Willis plant, where they would be used in over-the-road delivery of LNG from the plant to several LNG customers, including their largest, the Houston Metro system, which has a large fleet of LNG buses. At the time, Liquid Carbonic had a contract to provide LNG to Houston Metro, and several other bus facilities in Texas. The company felt it was in a competitive position to acquire more LNG contracts, and submitted a proposal to TRI to use it as a host fleet for an over-the-road heavy duty project. TRI suggested the project to NREL, which approved its setup. The project involved gathering data from three of Liquid Carbonic's LNG trucks, and one diesel control vehicle. The contracting of this project was simplified by the fact that the vehicles were leased, because that avoided the issue of using contract funds to purchase equipment. The first of the vehicles was delivered in January 1995, and the project began collecting data in February of that year.

\section{Difficulties with the Liquid Carbonic-Praxair Project and their Resolution}

The principal difficulty with the Liquid Carbonic-Praxair project arose from business circumstances that had nothing to do with the project. For a variety of reasons, described below, Liquid Carbonic's Willis facility lost much of its business, and the need to deliver transportation grade $99.5 \%$ pure methane LNG decreased significantly. This process occurred over a period of time, however, so meaningful data were gathered from the project.

Natural gas in pipelines is a chemical mixture; that is, it varies widely in content depending on its origin and what it has been mixed with in pipeline transportation. To the vast majority of natural gas users, this variation is of no significance, as the gas is burned simply to produce heat. In an internal combustion engine, however, gas content is significant, because too much inert nitrogen or ethane will cause driveability difficulties, or even major engine damage. 
The first reason for the loss of business related to the product purity issue noted above. Because most large users of LNG have been transit bus operators, usually municipal, the cost of the higher purity LNG sold by Liquid Carbonic caused it to lose bids on new business, or rebids on current contracts. Moreover, in the midst of the project, in August 1995, the Internal Revenue Service issued a ruling on the rate of federal excise taxation on LNG. That ruling set the tax rate of LNG as that of "other liquid fuels" which is $\$ 0.183$ per liquid gallon. This tax is significantly higher than $\$ 0.48$ per thousand cubic feet imposed on CNG, which is chemically identical. Moreover, because of the energy density difference between LNG and diesel fuel, its principal competitor in the heavy duty market, the tax rate actually penalized LNG by being equivalent to $\$ 0.31$ per diesel equivalent gallon-compared to $\$ 0.24$ per gallon of diesel. This unfavorable ruling, more than any other single factor, slowed all commercial truck LNG activity, because it dissuaded commercial trucking companies from even considering LNG because it made the fuel cost more than conventional diesel. ${ }^{10}$

In 1996, Liquid Carbonic was purchased by Praxair, a worldwide cryogenic products company. This purchase changed the company's business strategy, and one result of that change was a decision to leave the LNG business. The company continued to operate the LNG vehicles at the Willis terminal, but put the plant up for sale and asked to discontinue the project at the end of its second year of data collection, in April 1997.

As has happened in other projects, the changes in business conditions resulted in personnel changes, and many of the people who began the Liquid Carbonic-Praxair project are no longer with the company. This diluted the corporate memory and continuity needed to enhance the success of any project, especially as complex as operating trucks on alternative fuels. In the case of Liquid Carbonic-Praxair, the personnel changes interrupted the receipt of maintenance data, because necessary arrangements were not made by the host fleet with both Ruan, the leasing company, and Stewart and Stevenson, the local Houston DDC distributor. This difficulty is being overcome by TRI's intervention, and the necessary maintenance and repair data are being retrieved.

\section{The Detroit Diesel Corporation Project}

DDC is one of the nation's premier producers of heavy-duty engines for trucks and buses. The company has a long history of work in developing engines to operate on alternative fuels, and is the only U.S. engine manufacturer with engines certified in alcohol and natural gas fuels. DDC's most successful engines in recent years have been its Series 50 and Series 60 diesels. Both engines have been modified to operate on natural gas, and because DDC operates its own fleet of vehicles for parts distribution to and from its manufacturing facility in Detroit, the company

The Taxpayer Relief Act of 1997 finally removed the LNG penalty by setting a tax rate of $\$ 0.119$ per liquid gallon, which places it on a par, energy wise, with gasoline, whose tax rate is $\$ 0.183$. On this basis, it is actually advantaged compared to diesel, still taxed at $\$ 0.24$. The new rate was effective October 1,1997 . 
indicated its desire to use one LNG-powered vehicle in its fleet. The vehicle combined a Kenworth T400 chassis with a DDC Series 50G natural gas engine. The vehicle had been specially constructed by Kenworth and DDC for use in testing all aspects of the LNG fuel system, which included LNG tanks provided by MVE. TRI recommended the project to NREL, which approved it, and after contract negotiations, the project commenced in January 1996. Because DDC's truck fleet did not include a comparable diesel vehicle, it obtained NREL's permission to provide comparison data from a diesel control vehicle operated by a local company in Detroit, whose operations were similar to those of DDC's fleet.

\section{Difficulties with the Detroit Diesel Project and their Resolution}

DDC's project suffered the same difficulty as Con-Way, namely, the lack of suitable infrastructure support. At the time the project was initiated, DDC had installed a refueling facility, first located at TDM, a local DDC subcontractor, and later moved to DDC's facility, and was using the refueling rig for its engine testing work. It also allowed Gordon Foods, a local food distribution company that was operating one LNG-powered truck to use the facility. It was a temporary TVAC arrangement, and DDC arranged with Cryenco/ALT to make it permanent and modern by installing card readers and software management systems.

While the trucks were using the temporary rig, the drivers became disenchanted with the vehicles because of the waiting time for the station and its general unreliability. On one occasion, the truck actually ran out of fuel because the station could not be trusted to reflect the correct amount of fuel delivered.

Unfortunately, the efforts of Cryenco/ALT to upgrade and make the station more reliable met with insurmountable difficulties, and eventually, DDC decided to abandon its efforts. By that time, the truck had operated minimally, due in no small measure to the drivers' and dispatchers' distrust of the truck-fueling station system. As a result, TRI and NREL decided that continuing the project was not beneficial, and it was not renewed for data collection. It was an operational project only for 1996. Its contract called for several emissions tests to be run during the course of the project, but these were deleted from the contract when the project was discontinued.

\section{The Penske/Houston Airgas Project}

In July 1995, TRI was approached by Penske Leasing, one of the nation's leading truck leasing companies, and Penske informed TRI that one of its large accounts, Airgas Company, was interested in obtaining LNG-powered Class 6 trucks. Penske desired to lease the vehicles, but needed information on how to put them into the TRI/NREL program to help its customer bear the differential costs of the vehicles. Penske indicated that Airgas wanted to begin with a small number of trucks, two LNG and one diesel control, and, depending on the results of initial operations, acquire three more LNG and two more diesel control vehicles. Airgas is a large, multicity industrial gas company with its own fleet of vehicles in several cities. Initially, its intention was to host the LNG project in Mobile, Alabama. In the course of discussing the 
project, the company decided to base it in Houston, Texas, instead, because there was more variety in fuel availability in that city.

TRI recommended the project to NREL, and further recommended that because the host site was willing to consider running five LNG trucks, the project would be an excellent candidate for the NREL evaluation project. That effort, managed by Battelle Memorial Institute, involves a much more sophisticated data collection scheme than the demonstration projects that have fewer vehicles, and therefore do not yield statistically repeatable data. The project was approved and started in June 1996, with the first two LNG trucks and one diesel control vehicle. The project contract was written so that the added vehicles could be entered into service after Houston Airgas had enough experience to decide whether it wished to extend its LNG fleet.

\section{Difficulties with the Penske/Houston Airgas Project and their Resolution}

The most significant difficulty in this project is not really related to the project; rather, it is one of supplier support for the engine. At the same time several of the NREL/TRI projects involving DDC natural gas engines were being conducted, DDC ultimately concluded that it does not intend to commercialize these engines. Consequently, every project, this one included, will conclude having gathered some useful data, but will not put meaningful numbers of DDC natural gas engines into revenue service.

Once it became evident that DDC did not intend to advance its natural gas engines to commercial availability, Airgas concluded that it would not be in its interest, and Penske Leasing agreed, to obtain additional LNG trucks. The data gathering of the first phase will continue for the 3-year duration of the project, however, because DDC has indicated its intention to support the engines it has in the field. DDC has made good on this commitment to date.

Insofar as the project itself went, the trucks have operated in a satisfactory manner, generally, throughout the first year of service. The only really meaningful incident is the fact that one MVE fuel tank suffered a vacuum loss in the first year, and had to be removed and repaired by MVE. It is significant that this did not prove to be a difficult task; MVE repaired the tank effectively and returned it to service in a reasonable manner. Because this is the only incident of this nature experienced throughout the entire set of LNG truck demonstrations, all of which use MVE tanks, it is considered an isolated case, and does not warrant concern.

\section{Other TRI Activity}

\section{Natural Fuels Project}

As part of the overall TRINREL partnership, several unique activities have been undertaken and accomplished. The most striking of these, production of the SAE Recommended Practice for LNG heavy-duty trucks, has been described, and its result is a part of this report. One other activity was undertaken in January 1995 at the request of NREL, and that activity is still under way. It involves work by a Denver, Colorado, company, Natural Fuels, in determining and 
providing a natural gas fuel specification needed for both engine and vehicle testing for the DDC Series $50 \mathrm{G}$ natural gas engine. This fuel specification was to be in addition to the CARB specification. Natural Fuels has been given four tasks as part of this project. First, Natural Fuels plans to develop a natural gas motor fuel specification to represent the pipeline and distribution system gas available in the Denver area. Second, the company wishes to develop a similar specification to represent the pipeline and distribution system typically available to users in the greater high altitude Rocky Mountain area outside greater Denver. The third task is to conduct tests on the specified gas compositions, to be conducted by the National High-Altitude Heavy Duty Research and Technology Assessment Center in Denver, and the fourth task is to arrange for Federal Test Procedure (FTP) Heavy-Duty Engine Transient Emissions tests for the DDC Series 50 natural gas engine at the Colorado Institute of Fuels and Engine Research (CIFER) Laboratory.

\section{Difficulties with the Natural Fuels Project and their Resolution}

Natural Fuels was able to finish the first two tasks in a timely manner, and the reports that were the deliverables for Tasks 1 and 2 were provided in April 1995. These reports contained natural gas motor fuel specifications for Denver, Colorado Springs and Pueblo in response to task one ("Denver Gas"), using natural gas samples taken at the "Lipan Service Center" test point on the Public Service Company of Colorado distribution system for 1992, 1993, and 1994, approximately 260 days each year. For the Rocky Mountain area (outside the aforementioned cities) the composition data were obtained from four Colorado cities not included in Task 1, plus Denver International Airport, Albuquerque, New Mexico, and Salt Lake City, Utah. Samples were taken for varying periods of time in 1993 and 1994. It is referred to as "DIA Gas."

Completing Tasks 3 and 4 has proven far more difficult. The principal difficulties arose in installing and running the Series 50G engines in transit buses, and that, in turn, precluded Natural Fuels from obtaining the necessary emissions tests. The difficulties encountered were not part of the project, per se, but because of their nature, they prevented the completion of the tasks assigned.

First, Stewart and Stevenson, the subcontractor that was to install the engines for Natural Fuels into RTD buses, lost its right to perform on government contracts. Once that issue was resolved (it had nothing to do with this project), several other events created further delays. These were, respectively, contract negotiations between Stewart and Stevenson and RTD on the installation/testing process, and a CNG tank rupture on a bus in Metropolitan Los Angeles, which obliged a complete design review of the tank system. These matters caused the project to be dormant until January 1997, when the first bus began testing. The test protocol calls for five buses to run 30 days in revenue service, and then for one bus to be driven to 10,000 feet elevation. There, it will perform various tests using the "DIA" gas and undergo a chassis dynamometer performance/emissions test at the CIFER laboratory. 


\section{Lessons Learned and Advice for Fleets}

There are many lessons to learn from this TRI/NREL partnership to advance the testing of various alternative fuels in trucking operations. The first is that no matter how simple a project seems in the planning phase, it is always much more complex in its execution. This is the enhanced complexity lesson. Even though several projects seemed identical, they were individually essentially pioneering. Because of the nature of each project, and the varying numbers of participants, no two were really alike.

Enhanced complexity leads directly to increased time to start and complete. In no case did a project commence at the time it was originally expected to, not because of inattention or lack of motivation, but because of intervening events over which the project participants had no control. For instance, the ordering and delivery of the Midwest Ethanol Navistar trucks was significantly delayed by the initial contract negotiations (no truck could be ordered until the contracts were in place). These negotiations were protracted by the need for each host fleet jurisdiction to have its fuel supply, and a funding source for it fully in place before they could approve the ordering of vehicles. In the case of the LNG-powered vehicles, the intervention of the need to create an industry recommended practice forestalled forward movement on producing vehicles, because OEMs were hesitant to build and test vehicles in the absence of at least a draft document.

Another lesson arises is the need for continuity. In almost every instance, the individuals whose efforts and enthusiasm caused the project to be commenced were replaced before or during the course of the demonstration. There is no remedy for this occurrence, but it suggests the need for backup participants at every organization involved. This is frequently not possible, especially in "for profit" organizations, where costs of work multiply greatly if more people are involved. In the case of host fleets, if the project manager changes, or the project is turned over to someone not fully familiar with it, the success of the project is seriously jeopardized. 


\section{Appendix 1: Vehicle Specifications NREL-ATA Foundation Demonstration Projects}

Hennepin County, Minnesota: Ethanol

Nebraska Department of Roads, Nebraska: Ethanol

Ag Processing, Iowa: Biodiesel

United Parcel Service, Maryland: CNG

Los Angeles Times, California: CNG

Con-Way Western Express, California: LNG

Praxair (Liquid Carbonic), Texas: LNG

Penske/Airgas, Texas: LNG

Detroit Diesel Corporation, Michigan: LNG

USA Waste, Pennsylvania: LNG

\section{Hennepin County Project}

Fuel:

Ethanol (E95)

Chassis:

International Paystar 5070

Transmission:

Fuller RTX-11708LL

Engine:

DDC 9.05L 6V-92

300 hp @ 2,100 rpm

975 lb-ft @ 1,200 rpm

Number of trucks:

2 E95

1 diesel

Capacity:

E95: 100 gallons ( 1 tank)

Range:

GVW:

$200+$ miles

$50,000 \mathrm{lb}$

\section{Nebraska Department of Roads Project}

Fuel:

Ethanol (E95)

Chassis:

Transmission:

International Paystar 5070

Fuller RTX-11708LL

Engine:

DDC $9.05 \mathrm{~L} 6 \mathrm{~V}-92$

$300 \mathrm{hp} @ 2,100 \mathrm{rpm}$

975 lb-ft @ 1,200 rpm

Number of trucks:

2 E95

Capacity:

E99: 69 gallons ( 2 tanks)

Range:

$100+$ miles

GVW:

$50,000 \mathrm{lb}$ 


\section{AG Processing Project}

Fuel:

Biodiesel (65/35 Blend)

Chassis:

Kenworth T800

Transmission:

Eaton 14609, 9-speed

Engine:

DDC 11.1L Series 60

350 hp@1,800 rpm

1,350 lb-ft @1,800 rpm

Number of trucks: $\quad 6$ biodiesel

3 diesel

Chassis:

Mack R688ST

Transmission:

T2090,9-speed

Engine:

Mack 672 cu.in. E-6

350 hp @1,800 rpm

1,350 lb-ft @1,800 rpm

Chassis:

Freightliner FLD120

Transmission:

Eaton 14509, 9-speed

Engine:

Cummins $855 \mathrm{cu}$. in

315 hp @1,800 rpm

1,350 lb-ft @1,800 rpm

Range:

$450+$ miles

GVW:

$80,000 \mathrm{lb}$

United Parcel Service Project

Fuel:

$\mathrm{CNG}$

Chassis:

Transmission:

Engine:

GMC P-4 (UPS P-80 and P-100

package cars)

New Process 4-speed

Tecogen 4.3L

140 hp@4,000rpm

195 lb-ft @1,400 rpm

Number of trucks:

$20 \mathrm{CNG}$

5 gasoline

Capacity:

$2,360 \mathrm{scf}$ ( 2 cylinders)

Range:

150 miles

GVW:

$19,000 \mathrm{lb}$

\section{Los Angeles Times Project}

Fuel:

$\mathrm{CNG}$

Chassis:

Ford LTLA 9000

Transmission:

Eaton/Fuller RTLO-14610 B 
Engine:

Number of trucks:

Capacity:

Range:

GVW:

Fuel:

Chassis:

Transmission:

Engine:

Number of trucks:

Capacity:

Range:

GVW:

Fuel:

Chassis:

Transmission:

Engine:

Number of trucks:

Capacity:

Range:

GVWR:

Fuel:

Chassis:

Transmission:
DDC 12.7L Series 60G

$370 \mathrm{hp} @ 1,800 \mathrm{rpm}$

1,450 lb-ft @1,200 rpm

$1 \mathrm{CNG}$

1 diesel

11,448 scf ( 8 cylinders)

350 miles

$80,000 \mathrm{lb}$

\section{Con-Way Project}

LNG

Ford LN 8000

Eaton FS 7206-6 speed

Cummins C 8.3L

$250 \mathrm{hp} @ 2,400 \mathrm{rpm}$

750 lb-ft @ 1,400 rpm

2 LNG

2 diesel

200 gallons (dual tanks)

750 miles

$33,200 \mathrm{lb}$

Praxair Project

LNG

Kenworth T-400

Rockwell RM 1011 5AZ9001

DDC 12.7L Series 60G

370 hp @ 2,100 rpm

950 lb-ft @1,200 rpm

3 LNG

1 diesel

LNG - 120 gallons ( 2 tanks)

600 miles

$80,000 \mathrm{lb}$

\section{Penske/Airgas Project}

LNG

Freightliner FLD112646

Fuller RTX-1170911 
Engine:

Number of trucks:

Capacity:

Range:

GVWR:

Fuel:

Chassis:

Transmission:

Engine:

Number of trucks:

Capacity:

Range:

GVWR:

Fuel:

Chassis:

Transmission:

Engine:

Number of trucks:

Capacity:

Range:

GVW:
DDC Series 50G

300 hp @ 2,100 rpm

$1,000 \mathrm{lb}-\mathrm{ft} @ 1,200 \mathrm{rpm}$

$5 \mathrm{LNG}$

3 diesel

LNG - 120 gallons (2 tanks)

600 miles

$52,000 \mathrm{lb}$

\section{Detroit Diesel Project}

LNG

Kenworth T-400

Rockwell RM 1011 5AZ9001

DDC Series 50G

$300 \mathrm{hp} @ 2,100 \mathrm{rpm}$

$950 \mathrm{lb}-\mathrm{ft} @ 1,200 \mathrm{rpm}$

1 LNG

1 diesel

LNG - 120 gallons ( 2 tanks)

600 miles (est)

$80,000 \mathrm{lb}$

\section{USA Waste Project}

LNG

Mack MR

Allison HT741

Mack E7G

325 hp @ 1950 rpm

lb ft @ 1250 rpm

$7 \mathrm{LNG}$

1 diesel

150 gallons ( 2 tanks)

10 hours operations plus 80 miles transit

$74,000 \mathrm{lb}$ 


\section{Appendix 2: Members of the Manufacturers' LNG Technical Subcommittee of the Alternative Fuels Task Force}

Acurex Environmental Corporation Caterpillar

Chicago Bridge \& Iron

Columbia Gas of Ohio

Cryenco

Cummins Engine Company

CVI, Incorporated

Detroit Diesel Corporation

Drexel

Ecogas Corporation

Ford Motor Company

Freightliner Corporation
Gas Research Institute

Liquid Carbonic

Mack Trucks

Minnesota Valley Engineering, Inc.

Navistar International

PACCAR

Parker Hannifin Corporation

Penske Truck Leasing

Praxair

Ruan Transportation

Snyder Tank Corporation

Tecogen

Volvo-GM Heavy Truck Corporation 


\section{Appendix 3: Trucking Research Institute Alternative Fuel Demonstration Projects Project Contact Names}

\section{Hennepin County: Ethanol}

NREL Contract No. ZAZ-3-12223-01

Contact:

Barbara Sutey

Administrative Services Manager

Hennepin County Bureau of Public Services

320 Washington Avenue South

Hopkins, MN 55343

TEL: $612-930-2500$

FAX: 612-930-2513

Negotiations Initiated: June 1992

Data Collection Started: November 1993

Data Collection Completed: September 1996

Nebraska: Ethanol

NREL Contract No. AAC-3-13010-01-108189

Contact:

Ervan Ehrlich (1992 - September 1996)

Toms Sands (October 1996 - current)

Highway Fleet Manager

Nebraska Department of Roads

1500 Nebraska Highway 2

P.O. Box 94759

Lincoln, NE 68509-4759

TEL: $402-471-4567$

FAX: 402-479-4325

Negotiations Initiated: June 1992

Data Collection Started: September 1994

Data Collection Completed: June 1997

Praxair: LNG (formerly known as Liquid Carbonics, Inc.)

NREL Contract No. AAC-5-14445-01

Contact:

Norman Yale/Dave Forgash (1994 - April 1996)

Linda J. Bodicker (May 1996) 
Jeani Lothridge (June 1996 - current)

Praxair, Inc.

12114 Longstreet Road

Willis, TX 77378

TEL: 409-856-5550

FAX: 409-856-6075

Negotiations Initiated: August 1994

Data Collection Started: February 1995

Data Collection Completed: April 1997

\section{Detroit Diesel Corporation: LNG}

NREL Contract No. AAC-5-15131-01

Contact:

Paul Cassidy (1994-1995)

Roger E. Parry (1996 - current)

Program Manager

Detroit Diesel Corp.

13400 Outer Drive, West

Detroit, MI 48239-4001

TEL: $313-592-5090$

FAX: 313-592-5604

Negotiations Initiated: September 1994

Data Collection Started: January 1996

Data Collection Completed: December 1996

\section{United Parcel Service: CNG}

NREL Contract No. AAC-3-13272-01

Contact:

Robert Hall (1992 - June 1996)

Bob Williams (July 1996 - current)

Automotive Engineer

United Parcel Service

8440 Ardwick Ardmore

Landover, MD 20785

TEL: 301-386-8161

FAX: 301-386-8121

Negotiations Initiated: March 1993

Data Collection Started: August 1994

Data Collection Completed: July 1997 


\section{Los Angeles Times: CNG}

NREL Contract No. XC-1-11134-1

Contact:

Michael Jackson (February 1996 - current)

Business Development Manager

Acurex Environmental Corp.

555 Clyde Avenue

P.O. Box 7044

Mountain View, CA 94039

TEL: 415-254-2450

FAX: 415-254-2496

Negotiations Initiated: January 1994

Data Collection Started: December 1994

Data Collection Completed: January 1997

\section{AG Processing: Biodiesel}

NREL Contract No. AAC-5-14412-01

Contact:

John Campbell

Vice President

Ag Processing, Inc.

12700 West Dodge Road

P.O. Box 2047

Omaha, NE 68103-2047

TEL: $402-498-5546$

FAX: 402-498-2215

Negotiations Initiated: March 1994

Data Collection Started: January 1995

Data Collection Scheduled to be Completed: December 1997

\section{Con-Way: LNG}

NREL Contract No. AAC-5-15248-01

Contact:

John Glass, Con-Way Western Express (January 1995 - January 1996)

Therese Costa (February 1996 - current)

Project Manager

Acurex Environmental Corp.

100 N. Barranca St., \#500

West Covina, CA 91791-1600

TEL: 626-966-5535

FAX: 626-967-1568 
Negotiations Initiated: January 1995

Data Collection Started: December 1995

Data Collection Scheduled to be Completed: April 1999

Penske: LNG

NREL Contract No. ACV-6-16606-01

Contact:

Marc Althen

Vice President, Environmental Services

Penske Truck Leasing Co.

Route 10 Green Hills

P.O. Box 563

Reading, PA 19603-0563

TEL: $610-775-6268$

FAX: 610-775-6442

Negotiations Initiated: July 1995

Data Collection Started: June 1996

Data Collection Scheduled to be Completed: May 1999

William H. Martin: LNG (formerly known as Chambers Development Corp.)

NREL Contract No. AAC-5-15249-01

Contact:

Gary Simmons (1993 - 1996)

Ben Woods (1997 - current)

District Manager

Wm. H. Martin - USA Waste

200 Rangos Lane

Washington, PA 15301

TEL: $412-228-4200$ ext. 20

FAX: 412-225-2630

Negotiations Initiated: April 1992

Data Collection Scheduled to Start: October 1997

Data Collection Schedule to be Completed: March 2000

Trucking Research Institute

Additional Alternative Fuels Work

Contact Names

Natural Fuels: LNG

NREL Contract No. AAC-5-15096-01

Contact:

Paul Nelson 
Vice President

Natural Fuels Corporation

5855 Stapleton Drive North

Denver, CO 80216-3312

TEL: 303-322-4600

FAX: 303-322-4644

Negotiations Initiated: November 1994

Data Collection Started: January 1995

Data Collection Scheduled to be Completed: October 1997 


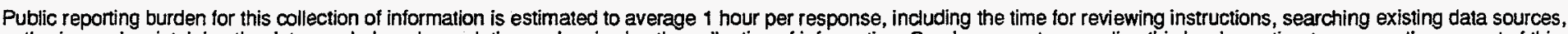

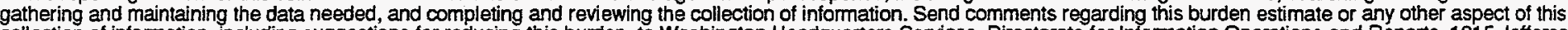

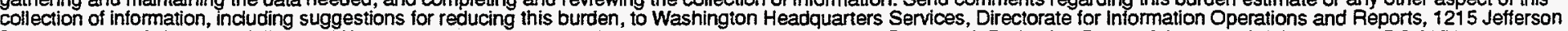

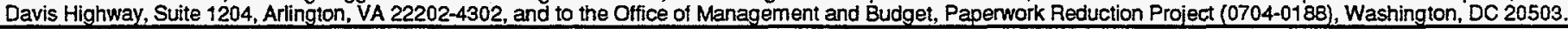
1. AGENCY USE ONLY (Leave blank)
2. REPORT DATE
3. REPORT TYPE AND DATES COVERED
February 1998
Subcontract report

\section{TITLE AND SUBTITLE}

Demonstrating and Evaluating Heavy-Duty Alternative Fuel Operations

\section{AUTHOR(S)}

William Peerenboom

Trucking Research Institute

\section{PERFORMING ORGANIZATION NAME(S) AND ADDRESS(ES)}

Trucking Research Institute 2200 Mill Road

Alexandria, VA 22314-4677

\section{SPONSORING/MONITORING AGENCYNAME(S) AND ADDRESS(ES)}

National Renewable Energy Laboratory

1617 Cole Boulevard

Golden, CO 80401-3393

\section{FUNDING NUMBERS}

(C) XC-1-11134-1

(TA) FU703330

\section{SUPPLEMENTARY NOTES}

\section{2a. DISTRIBUTION/AVAILABILITY STATEMENT}

National Technical Information Service

U.S. Department of Commerce

5285 Port Royal Road

Springfield, VA 22161 12b. DISTRIBUTION CODE

UC-1504

13. ABSTRACT (Maximum 200 words) This report describes the activities of the Trucking Research Institute (TRI) in support of the National Renewable Energy Laboratory's work as field manager to implement Section 400BB of the Alternative Motor Fuels Act. The principal objective of the projects described was to understand the effects of using an alternative fuel on a truck fleet, through actual operation of the trucks. The report presents the lessons learned.

\section{SUBJECT TERMS}

Alternative fuels, transportation fuels, heavy-duty trucking, fleet operations
18. SECURITY CLASSIFICATION OF THIS PAGE
19. SECURITY CLASSIFICATION OF ABSTRACT
15. NUMBER OF PAGES

35

16. PRICE CODE

20. LIMITATION OF ABSTRACT 